\title{
Uniparental disomy - clinical consequences due to imprinting and activation of recessive genes
}

Thomas Liehr

From International Conference on Human Genetics and 39th Annual Meeting of the Indian Society of Human Genetics (ISHG)

Ahmadabad, India. 23-25 January 2013

Uniparental disomy (UPD) is often considered as an event to be characterized exclusively by molecular genetic or epigenetic approaches. Still in at least one third of cases UPD emerge in connection with or due to a chromosomal rearrangement.

Till date $\sim 2,500$ UPD cases detected in clinical, nontumor cases are reported in the literature (http://www. fish.uniklinikum-jena.de/UPD.html). Based on this, the presently known imprinting syndromes, chromosomal contribution to UPD phenomenon, and cytogenetic subgroups of UPD and segmental UPD are reviewed.

UPD may arise in clinical cases, as well as it may be exclusively tumor related. For clinical cases imprinting is quantitatively the most important problem. Still isodisomy may also be a problem, due to "activation" of recessive mutation-events, thus inducing rare autosomal recessive disorders.

Overall, as UPD is more but an interesting rarity, the genetic background of each "UPD-patient" needs to be characterized besides by molecular methods, also by molecular cytogenetics in detail.
Submit your next manuscript to BioMed Central and take full advantage of:

- Convenient online submission

- Thorough peer review

- No space constraints or color figure charges

- Immediate publication on acceptance

- Inclusion in PubMed, CAS, Scopus and Google Scholar

- Research which is freely available for redistribution 